the 1940s, I find it hard to conclude that American unionists needed to succumb to virulent anti-communism or to purge leftists.

Luff provides a marvelous, deeply researched, groundbreaking study on anti-communism within the ranks of conservative labour. Her richly nuanced account of labour anti-communism will shape and inform studies that follow. Those days of the red scare are gone, Luff insists in her conclusion, and we now have perhaps the most inclusive and progressive labour leadership in our history - or what is left of it. But the deeply disturbing effects of anti-communism on the labour movement remain to be reckoned with. Perhaps the revelations, if one can call them that, of the Soviet archives have hazed over our understanding of the fundamental role of anti-communism as a means to divide and destroy all movements for social change. In Commonsense Anticommunism we gain a deeper understanding of how it all happened, but I can't help but feel that an important part of the story is missing.

Michael Honey

University of Washington

\title{
Erik S. McDuffie, Sojourning For Freedom: Black Women, American Communism and the Making of Black Left Feminism (Durham NC: Duke University Press, 2011).
}

\section{Expanding the Boundaries of the Black Radical Feminist Movement}

Erik S. McDuffie's Sojourning For Freedom: Black Women, American Communism and the Making of Black Left Feminism is an engaging study that considers the impact of pioneering African American radical female activists from the early twentieth century through to the 1970s, their involvement in the U.S. Communist Party (CPUSA) between 1919 and 1956, and the ways in which they advocated for a pathbreaking politics committed to black liberation, women's rights, decolonization, economic justice, peace and international solidarity. Chronicling their varied and complex journeys through the Communist Left, McDuffie provides a theoretical and empirical template for valuing how the Left served as a key site where African American women forged an innovative transnational radical black feminist politics that laid the groundwork for black feminism of the 1970s. In examining how these women negotiated race, gender, class, sexuality and politics within the CPUSA and came to understand themselves as diasporic and transnational citizens, McDuffie demonstrates that the Communist Left served as a principle site for black women radicals to agitate for civil rights and black women's dignity outside of more traditional sites such as women's clubs, the church, and civil rights and black nationalist groups. 
Throughout the study, McDuffie argues that black women community organizers, social workers, artists, domestic workers, teachers and writers enlisted in the Old Left because they saw it as a powerful global vehicle. McDuffie contends that while their politics were "leftist," black left feminists saw no contradiction in pursuing, often simultaneously, interracial, left wing, separatist, liberal, local and internationalist political strategies. Their central focus was on winning tangible victories for disfranchised black communities and workers, and for victims of social injustice and racial violence, particularly black female survivors of interracial sexual assault. McDuffie argues that above all, an affiliation with the CPUSA helped these radical black women realize that given their unique racial, gendered, and class standpoint, they possessed an awareness of their "multiple consciousness."

In six chronological and thematic chapters, McDuffie examines black communist women pioneers within the context of the first red scare and the interwar period, the battle over Scottsboro and Harlem's survival, black women's contribution to forming the popular front, and their fight against Jim Crow, Fascism, colonialism and the Cold War. Across these chapters, McDuffie importantly moves African American women from the margins to the center of narratives regarding early black radicalism, diasporic social movements, transnational women's movements and American Communism. By situating these women within a complicated national and global nexus, McDuffie challenges the common depiction of black feminists solely as local grassroots organizers and demonstrates that black left feminists grounded their ideas in the complex history of American and global Communist movements, black radicalism and feminism.

Drawing from a wide variety of sources, McDuffie's study is a welcomed intervention within the current historiography of early African American feminism. Until recently, scholarship has almost exclusively focused on the church, women's clubs and the Garvey movement. In a critical rupture of this scholarly tradition, McDuffie draws on more than 40 oral histories and personal papers collected from veteran black women radicals and their families, CPUSA records, Communist, African American and mainstream newspapers, and various archival materials from the Communist International, black left and non-Communist-affiliated black protest groups, and FBI surveillance files. In using these materials, McDuffie has rendered visible the collective efforts of black Communist women who defiantly rejected middle class political agendas and the cultural sensibilities of traditional black protest groups.

McDuffie's analysis is also unique in that he is working against much of the recent scholarship on 1960s and 1970s black feminist organizations that has either focused on recovering black women's involvement in "second wave feminism" or charted how these women fashioned their own distinct feminist politics. McDuffie reminds readers that the signature black feminism theoretical paradigm of triple oppression originated with black left feminists. In doing so, he suggests 